\title{
Globalization, social exclusion and work: with special reference to informal employment and gender
}

Working Paper No. 20

Marilyn Carr and Martha Chen

Policy Integration Department

World Commission on the Social Dimension of Globalization

International Labour Office

Geneva

May 2004

Working papers are preliminary documents circulated

to stimulate discussion and obtain comments 
Copyright @ International Labour Organization 2004

Publications of the International Labour Office enjoy copyright under Protocol 2 of the Universal Copyright Convention. Nevertheless, short excerpts from them may be reproduced without authorization, on condition that the source is indicated. For rights of reproduction or translation, application should be made to the Publications Bureau (Rights and Permissions), International Labour Office, CH-1211 Geneva 22, Switzerland. The International Labour Office welcomes such applications.

Libraries, institutions and other users registered in the United Kingdom with the Copyright Licensing Agency, 90 Tottenham Court Road, London W1T 4LP [Fax: (+44) (0)20 7631 5500; email: cla $a$ cla.co.uk], in the United States with the Copyright Clearance Center, 222 Rosewood Drive, Danvers, MA 01923 [Fax: $(+1)(978) 750$ 4470; email: info acopyright.com] or in other countries with associated Reproduction Rights Organizations, may make photocopies in accordance with the licences issued to them for this purpose.

ISBN 92-2-116009-2 (printed version)

ISBN 92-2-116010-6 (web version)

First published 2004

Cover:

The designations employed in ILO publications, which are in conformity with United Nations practice, and the presentation of material therein do not imply the expression of any opinion whatsoever on the part of the International Labour Office concerning the legal status of any country, area or territory or of its authorities, or concerning the delimitation of its frontiers.

The responsibility for opinions expressed in signed articles, studies and other contributions rests solely with their authors, and publication does not constitute an endorsement by the International Labour Office of the opinions expressed in them.

Reference to names of firms and commercial products and processes does not imply their endorsement by the International Labour Office, and any failure to mention a particular firm, commercial product or process is not a sign of disapproval.

ILO publications can be obtained through major booksellers or ILO local offices in many countries, or direct from ILO Publications, International Labour Office, CH-1211 Geneva 22, Switzerland. Catalogues or lists of new publications are available free of charge from the above address, or by email: pubvente $a$ ilo.org

Visit our website: WwW.ilo.org/publns

Printed by the International Labour Office, Geneva, Switzerland 


\section{Globalization, social exclusion and work: with special reference to informal employment and gender}

\section{Contents}

Foreword iii

Preface. $\mathrm{v}$

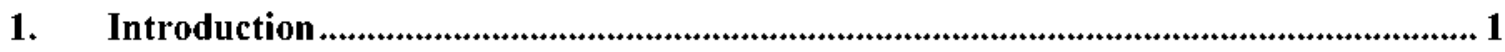

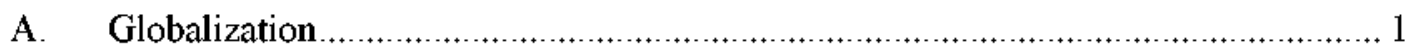

1. Reorganization of production into global production systems: The export link ........... I

2. Competition within domestic production systems: The import link .............................3

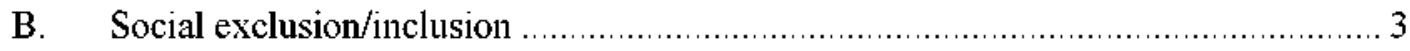

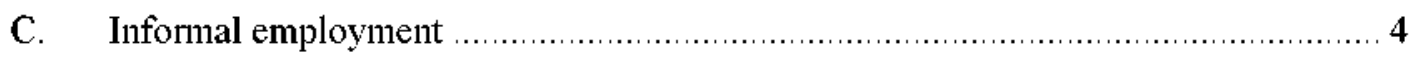

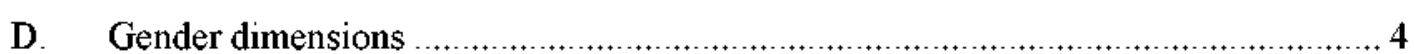

2. Globalization, social exclusion and work

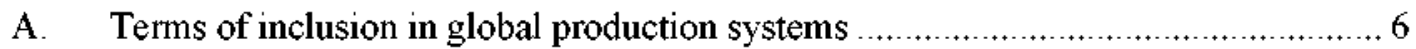

B. Barriers to inclusion in global production systems ........................................ Il

C. New forms of exclusion in domestic production systems following the

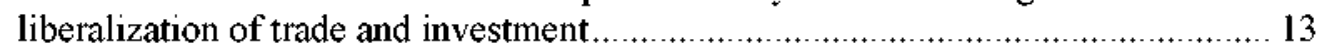

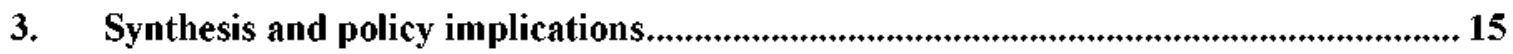

A. General conclusions regarding social exclusion in the realm of work .................. 15

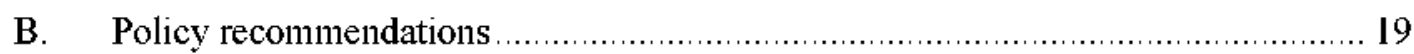

C. Closing observations: Social exclusion and poverty ……................................... 23

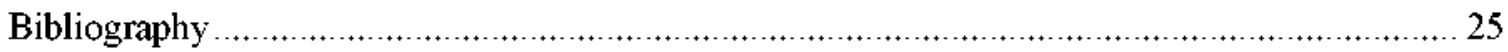





\title{
Foreword
}

In February 2002, the ILO established an independent World Commission on the Social Dimension of Globalization, co-chaired by President Tarja Halonen of Finland and President Benjamin Mkapa of Tanzania and comprising 26 eminent commissioners from a wide range of walks of life and different parts of the world, each serving in their individual capacity. Its broad goals were: to identify policies for globalization that reduce poverty, foster growth and development in open economies, and widen opportunities for decent work; to explore ways to make globalization inclusive, so that the process can be seen to be fair for all, both between and within countries; to promote a more focused international dialogue on the social dimension of globalization; to build consensus among key actors and stakeholders on appropriate policy responses; and to assist the international community forge greater policy coherence in order to advance both economic and social goals in the global economy.

The report of the World Commission, A fair globalization: Creating opportunities for all, was released on 24 February 2004. It is available on the Commission's website www.ilo.org/public/english/wcsdg/index.htm.

A secretariat was established by the ILO to support the Commission. Among other tasks, it compiled information and commissioned papers on different aspects of the social dimension of globalization. The aim was to provide the Commission with documentation and data on a wide range of options and opinions concerning subjects within its mandate, without committing the Commission or individual Commissioners to any particular position on the issues or policies concerned.

Material from this background work is being made available as working papers, as national and regional reports on meetings and dialogues, and in other forms. Responsibility for the content of these papers and publications rests fully with their authors and their publication does not constitute an endorsement by the World Commission or the ILO of the opinions expressed in them.

\author{
Gerry Rodgers \\ Director \\ Policy Integration Department
}





\section{Preface}

The Technical Secretariat to support the World Commission on the Social Dimension of Globalization first prepared a synthesis of ILO activities on the Social Dimension of Globalization (published as Working Paper No. 1 in this series). Documentation on the work and outcomes of other major commissions, an ideas bank, a database and knowledge networks of experts and social actors were subsequently developed. These networks have dealt with several topics, including: inclusion at the national level for the benefits of globalization to reach more people; local markets and policies; cross-border networks of production to promote decent work, growth and development; international migration as part of the Global Policy Agenda; international governance (including trade and finance); the relationship between culture and globalization; and values and goals in globalization. Gender and employment aspects were addressed throughout this work. The Reports on the Secretariat's Knowledge Network Meetings are available on the Commission's web site or in a special publication from the ILO (ISBN 92-2-1157I1-1).

During the course of these activities, a number of substantive background papers were prepared, which are now made available for wider circulation in the Policy Integration Department's Working Paper series (Nos. 16 to 38), as well as on the Commission's website

Dr. Carr and Dr. Chen, both actively involved in Women in Informal Employment Globalizing and Organizing (WIEGO), look at patterns of social exclusion and inclusion in the realm of work from the perspective of the working poor, especially women, in developing countries. They identify different processes of social exclusion and inclusion, rather than to assess their causes or measure their impact. In the European context, most analyses focus on exclusion from employment opportunities. In developing countries, the concept of unemployment is somewhat problematic. The paper focuses therefore on the nature of employment opportunities associated with globalization: notably, the terms of inclusion (of paid workers) and the barriers to inclusion (of the self-employed) in global production systems; and the forms of exclusion from domestic production systems associated with increased imports and other dimensions of trade liberalization. The authors discuss examples relating to three broad processes of social exclusion and inclusion: the terms of inclusion of paid workers in global production systems; the barriers to inclusion of the self-employed in global production systems; and the patterns of exclusion from domestic production systems associated with imports and other aspects of trade liberalization.

They see the social outcomes of global integration as not somehow being the "natural" outcomes of market forces, but rather as "political" outcomes determined by the choices, which gives reason for optimism, as it is possible to change policies if it is understood how these dominant institutions and processes work. They argue that there is no single "magic" bullet for policy solutions. For the self-employed, a mix of promotional measures is required. For paid workers, a mix of protective measures is needed. In addition, policy and regulatory reforms, to correct for systemic biases against labour and informal labour in particular, are necessary as well as institutional reforms to strengthen organizations of informal workers/producers and to promote their representation in relevant policy formulation and rule-setting institutions.

\section{Rolph van der Hoeven \\ Manager, Technical Secretariat \\ World Commission on the Social Dimension of Globalization}

May 2004 



\section{Globalization, social exclusion and work: with special reference to informal employment and gender}

\section{Introduction}

This paper seeks to look at patterns of social exclusion and inclusion in the realm of work from the perspective of the working poor, especially women, in developing countries. The aim is to identify different processes of social exclusion and inclusion, rather than to assess their causes or measure their impact. In the European context, most analyses of social exclusion and employment focus on long-term unemployment or barriers to employment, or in other words, on exclusion from employment opportunities. In developing countries, where the majority of the workforce has never had secure long-term employment, the concept of unemployment is somewhat problematic. Instead of unemployment per se, the paper focuses on the nature of employment opportunities associated with globalization: notably, the terms of inclusion (of paid workers) and the barriers to inclusion (of the selfemployed) in global production systems; and the forms of exchusion from domestic production systems associated with increased imports and other dimensions of trade liberalization. It is hoped that the paper will contribute to ongoing efforts to extend and modify the concept of social exclusion to fit the reality of the developing world, and more specifically the reality of work in the developing world.

The first section contains a description of the context in which the paper is set by defining the terms used and reviewing some of the current issues relating to social exclusion and inclusion. The second section provides and discusses examples relating to three broad processes of social exclusion and inclusion associated with globalization: the terms of inclusion of paid workers in global production systems; the barriers to inclusion of the selfemployed in global production systems; and the patterns of exclusion from domestic production systems associated with imports and other aspects of trade liberalization. The final section draws out the implications of the examples cited for: the analysis of social exclusion in the context of developing countries; and the formulation of policy to address social exclusion associated with global economic integration.

\section{A. Globalization}

This paper is concerned with the economic aspects of globalization: namely, specific processes of economic integration that are driven by trade liberalization, the related economic reforms and information communication technology. More specifically, it focuses on the reorganization of production into global production systems, notably global value chains and export processing zones, and the reorganization of domestic production in response to trade liberalization. These related processes are compared and contrasted with examples from a few key sectors (garments, non-timber forest products, food processing, horticulture and construction) in selected countries (Chile, India, Kenya, Sri Lanka, Mexico, Peru, the Philippines, South Africa, Thailand, Uganda and Zimbabwe).

1. Reorganization of production into global production systems: The export link

The world economy has changed in very significant ways over recent decades. One dimension of these changes is the reorganization of production into global production systems, of which the best known are global value chains and export processing zones. Although they interact in complex ways, each of them are considered to be different "systems" in the sense that what drives and governs them is identifiable and distinctive. 
"Value chain" is the term used to describe the chain of activities - the various stages at which value is added - that brings a product from its conception to the final consumer. The term "global value chain" is used when the process has become globalized: that is, when the process takes place across different parts of the world. "Export processing zones" are industrial zones with special incentives set up to attract foreign investment. The best know variant of these are manufacturing enclaves in which imported materials undergo some degree of processing before being exported again (ILO, 1998). More and more countries, however, are moving beyond enclave-type zones engaged in simple processing activities to attract different categories of investment.

Both systems are credited with creating new jobs. In the past, this has generally been the case. However, employment in global value chains is often precarious, as lead companies are likely to shift the location of production from one country to another, depending on the competitive advantages, including the incentive packages offered in different countries. Moreover, export processing zones in several countries have recently shifted to more capital-intensive productive processes which require either fewer workers or more skilled workers.

It is important to note that self-employed/own account workers operating outside export processing zones are also involved in global production systems to varying degrees. Some are absorbed into them against their will and on terms that are unfavourable to them. Others actively seek out links with higher value export markets - inevitably through some sort of production chain - but are not always successful in achieving their objective because of barriers to entry. Also, investment by large corporations in export-oriented production/processing activities using local resources and raw materials may deplete the supply or raise the price of these natural resources, forcing previously self-employed persons - for example, small-scale farmers or fisherfolk - to become dependent wage workers without independence or security.

It is also important to note that the analytical distinction between global value chains and export processing zones becomes blurred in real life. This is because zone enterprises supply to global value chains and global value chains subcontract to export processing zones. However, except when a zone is set up by and supplies to a single foreign company, zone enterprises often supply to more than one global value chain. And many global value chains are linked to more than one zone, and even to multiple zones in different countries. Moreover, not all enterprises linked to global value chains operate from a zone.

There are also some striking commonalities across zones and chains. In both types of system there is a marked shift in focus: (a) from employer-employee relationships to firm-government relationships (in the case of zones) or to inter-firm relationships (in the case of chains); and (b) from concerns of production (and workers) to concerns of distribution (and consumers). These shifts are accompanied by parallel processes of exclusion and inclusion. For instance, in their efforts to attract foreign direct investment, governments often exempt export processing zones from taxation and regulations that would otherwise obtain within their countries, thereby encouraging employment relationships that are not covered by labour legislation or social protection. In global value chains, the lead firms tend to negotiate directly with only the first tier of subcontracting firms, thereby retaining power and control within the chains and excluding those down the chain from direct negotiations and associated benefits.

Finally, although they interact in complex ways, it is important to bear in mind the differences between global value chains and export processing zones. In practice, most export processing zones are established and governed by local governments, while most global value chains are driven and governed by lead buyer or producer firms in the North. 
To understand patterns of exclusion and inclusion in each system, it is necessary to understand their various dimensions, including: their input-output structure and associated economic relationships; their geographical location(s) and spatial organization; the governance structure and power relationships of the system (who is "driving" the chain or zone); and the regulatory influences, both national and international (Gereffi, 1999).

2. Competition within domestic production systems: The import link

Other notable dimensions of recent economic change include trade liberalization and the associated movement of goods, both within and between countries. While these changes often produce efficiency gains, they can also give rise to greater volatility in product and labour markets, which impinge directly on unskilled workers and the self-employed (Jhabvala and Kanbur, 2002). Despite the benefits of liberalization, its troubling features for unskilled workers include not only loss of employment, but also a decline in wages, bargaining power and/or work security. Each of these features in turn reflects aspects of social exclusion: in this case, exclusion not only from work opportunities, but also from the wage and non-wage benefits of employment. Each of these features is also associated with one or more types of change induced by imported goods and trade liberalization more generally, including changes in demand, technology, competition and/or institutional arrangements. Most notably, cheap imports of food and other consumer goods often lead to the destruction of markets for goods produced domestically by own account workers and small/micro-enterprises.

\section{B. Social exclusion/inclusion}

As originally conceptualized in Europe, social exclusion referred to the exclusion of citizens by the State from the social contract and, more specifically, from standard secure employment. Recently, the concept has been extended to developing countries and has been broadened to refer to the processes by which certain groups are excluded from or marginalized by social, economic and political development. The process of extension has necessarily led to a fundamental rethinking of the concept. This is because the context of most developing countries does not match that of most countries in Europe. In recent years, most European countries have experienced an erosion of full employment and of the welfare state. Nevertheless, in most European countries the majority of workers still have standard wage work and the majority of citizens are relatively well off. Most developing countries, by contrast, have never experienced full employment or developed a fullyfledged welfare state. As a result, the majority of workers are either self-employed or have non-standard wage jobs, and the majority of citizens are relatively less well off.

As noted earlier, this paper focuses on patterns of social exclusion and inclusion in the realm of work from the perspective of the working poor in the informal economy. It examines the terms of and barriers to inclusion in global production systems and the processes of exclusion associated with the liberalization of domestic production systems. It also addresses the inherent tension for the working poor between being included in the global economy and the terms of their inclusion, including the loss of (or exclusion from) economic security, worker rights/benefits, bargaining power and "voice". Due to lack of data and time, the outcomes of these patterns are not addressed in terms of poverty or inequality. 
C. Informal employment

The new concept of "informal employment" proposed by the ILO in its report to the International Labour Conference in 2002 and in a companion booklet of statistics on the informal economy defines informal employment as employment without secure contracts, worker benefits or social protection (ILO, 2002a and 2002b). It is comprised of two basic components: self-employment in informal enterprises and paid employment in informal jobs. The informal self-employed include employers who hire others, own account workers and unpaid contributing family members. Informal paid workers include casual day labourers, domestic workers, industrial outworkers and various types of contract workers.

The idea is that both types of informal employment - self-employment and paid employment - are associated with the lack of secure contracts, worker benefits or social protection, as well as low average earnings. Of course, there are differences between the two sub-groups. In general, the self-employed face problems of exclusion from capital and product markets, while paid workers face unfavourable terms of inclusion in labour markets. But both typically lack bargaining power in the markets within which they operate, both labour markets and other factor markets, and are both typically excluded from social protection. Most self-employed, especially own account workers, as well as informal paid workers, cannot afford to pay for their own social protection. Few informal paid workers are likely to have employment-based protection. And few informal workers or producers are likely to receive much by way of protection from the State.

The old concept of the "informal sector" was defined in terms of the characteristics of the enterprise (small, unregistered), whereas the new concept of "informal employment" is defined in terms of the characteristics of employment relations (without secure contracts, worker benefits or social protection). The old concept of the "informal sector" included the self-employed in informal enterprises and paid workers in informal enterprises. But it did not include casual labourers with no fixed employer, domestic workers who work for households, homeworkers and other industrial outworkers who work under subcontracts for either formal or informal firms or undeclared workers for either formal or informal firms. Under the new concept, paid employment in informal jobs includes all of these categories, as well as the employees of informal enterprises.

By defining informality in terms of employment status or employment relationships, the new concept of informal employment represents a major conceptual shift. To begin with, it transfers some of the responsibility for informality from the informal workforce to formal structures (public and private). The thinking associated with the old concept of the informal sector assumed that informal enterprises were avoiding formality, namely registration and taxation. The new thinking associated with the concept of the informal economy assumes that those concerned would like the benefits of formality: namely, secure work, worker benefits, social protection and voice, but that formal enterprises or the formal regulatory system serve to "exclude" them from these benefits. Under the new conceptualization, informal employment is seen as resulting from a process of exclusion from the non-wage benefits of employment.

\section{Gender dimensions}

This paper reviews some, but not all, of the gender implications of the patterns of social exclusion/inclusion in the realm of work associated with globalization. The focus is on the intersection of gender identities with work identities. In so doing, we acknowledge that globalization often affects men and women workers differently. But we hasten to add that "women workers" and "men workers" are not homogeneous groups and that globalization affects different groups of women and men workers differently. In our understanding, the 
impact of economic globalization (including associated patterns of social exclusion/inclusion) on workers, both male and female, depends on the type of work in which they are involved (for example, wage work or own account production), as well as their age, literacy/education and ethnicity. Where they live and work is also very significant, as there are large differences in national and local policies.

Ascribed identities - notably ethnicity and gender - are often a source of either exclusion or inclusion at work. This is manifested, for instance, in the segmentation of labour markets along the lines of gender, ethnicity or some mix of the two. Consider, for example, the complex interplay of gender, caste and religion in determining who does what work in Ahmedabad City, India. In Ahmedabad, as elsewhere in India, women are over-represented in the informal economy, in the sense that a greater share of women workers than of men are engaged in the informal economy. In the case of Ahmedabad, over 80 per cent of women workers and 65 per cent of men workers are engaged in the informal economy. There are also gender differences within the informal economy in terms of employment status and place of work. Among women who work in the informal economy, an insignificant percentage are employers, surprisingly few are independent own account operators, while most are either casual workers, homeworkers or unpaid family workers. Indeed, the share of women who are homeworkers is almost ten times that of men and more than twice the share of women who are independent own account workers.

In many communities, traditional barriers still prevent women from going out of their homes to work. In Ahmedabad City, and elsewhere in India, this is particularly true of Muslim women, but also of Hindu women in many of the higher castes. For some women, having primary or sole responsibility for household duties, including childcare, also prevents them from working outside their homes or areas of residence. This means that there are marked gender differences in the place of work in Ahmedabad City: nearly 70 per cent of women, compared to fewer than 10 per cent of men, work in their own or their employer's home; fewer than 8 per cent of women, compared to over 27 per cent of men, work on the streets or at construction sites; and fewer than 22 per cent of women, compared to nearly 60 per cent of men, work in factories or offices. There are also marked differences among groups of women in regard to the location of work. Most Muslim women and upper caste Hindu women work from their homes, if they work at all. Compared to upper caste Hindu women, a higher percentage of middle caste women and a far higher percentage of lower caste women are in the paid labour force and work outside the home.

A great deal has been written, in India and elsewhere, about why women work from their homes. Two schools of thought focus on supply side factors. One argues that women prefer or opt to work at home because of the location and flexibility of work hours, which allow them to combine or juggle paid work, domestic chores and care work. The other argues that women are conditioned by prevailing gender norms to assume this triple workload and/or to restrict their mobility and do not therefore opt, but are forced to work at home. A third school of thought focuses on the demand for labour and argues that prevailing gender norms are reflected in gendered patterns of employment opportunities. Our findings suggest that all these factors contribute to the concentration of women in home-based activities and to gender segmentation in both the formal and informal economy.

In brief, this paper does not attempt to assess the impact of globalization on women. Instead, we attempt an analysis, with examples, of how the following articulate with each other: socially-defined relationships and identities (gender, ethnicity, race or religion); work-related identities; the emergence of global production systems and shifts in domestic production systems associated with globalization; and forms and patterns of social exclusion/inclusion. 
Patterns of social exclusion within the realm of work vary not only by gender and type of work, but also by sector of the economy, by system of production and between regions. It has therefore been necessary to make a choice as to how best to communicate these complex patterns given the limits of time and space. In this paper, it has been decided to focus on the complex interplay of social exclusion and inclusion from the perspective of informal workers and producers who are linked, either through exports or imports, with the global economy.

\section{Globalization, social exclusion and work}

As explained above, the interface between global production systems and social exclusion varies according to who you are, where you live and how you make a living. It also varies over time with changes in national and international policies relating to trade and investment.

This section seeks to illuminate how some of the more significant changes that are taking place in global production systems are impacting on the social exclusion/inclusion of those producers/workers who are traditional inhabitants of, or new entrants to the informal economy, with special reference to women producers and workers. In so doing, it takes examples from a range of countries in Asia, Africa and Latin America/Caribbean (with a few examples from Europe and North America) and includes both self-employed/own account workers and paid workers in the informal economy.

Three different types of change are explored

(a) cases in which export-led growth and development have resulted in the increased inclusion of workers in the global economy, but on questionable/undesirable terms and with uncertain sustainability;

(b) cases in which barriers to entry have prevented the self-employed/own account workers from taking advantage of new economic opportunities arising from the liberalization of trade and investment; and

(c) cases in which the liberalization of trade and investment have resulted in the destruction of domestic enterprises or paid jobs through; the flooding of the market with cheap imports/services competing on unequal terms for local natural resources and changing technologies and skill demands.

\section{A. Terms of inclusion in global production systems}

Export-led manufacturing. One of the best known features of globalization is the massive creation of jobs in export-led manufacturing in developing countries, particularly in SouthEast/East Asia and in Central and South America. Starting in the 1960s, this was encouraged through the creation of export processing zones (EPZs) which offered incentives to foreign corporations in terms of tax holidays, cheap labour rates and lack of unionization of the workforce. While EPZs had many problems (including their isolation from surrounding communities and the consequent alienation of workers, the majority of whom had migrated from other locations), they did nevertheless create a significant number of jobs, especially for young women. For some of these women, employment in EPZs represents a welcome alternative to less favourable forms of work elsewhere or a means of escape from an oppressive home environment. The most recent figures suggest that 27 million jobs had been created in these zones as of 1995 , of which 70 to 80 per cent were for women, mainly in labour-intensive industries such as garments, footwear and electronics. 
More recently, multinational corporations have turned away from direct foreign investment in production in developing countries and moved towards the coordination of global production chains, in which they concentrate on retail and distribution, while outsourcing production to domestic companies. Although some production still takes place within EPZs, global production chains are now more widely spread within the economy and incorporate a whole range of subcontracting arrangements, including home-based workers who operate through small, medium and large contractors and firms involved in the chains. These so-called "buyer-driven" commodity chains still concentrate on labour-intensive products and still involve a largely female workforce. Women remain segregated and concentrated at the margins of the production process and at the lower end of the commodity chain in these female-intensive subsectors. Typically they account for less than 10 per cent of the total sale price of what they produce, lack any say in their working conditions and have no means of redressing the balance of power and returns.

While these trends have undoubtedly led to the creation of new employment opportunities for women in the countries concerned and have enabled them to be integrated into the global economy, several issues need to be taken into consideration when evaluating their impact in relation to social exclusion and inclusion.

First, while export-led industrialization has created new jobs for women in many countries, the quality of this employment needs to be questioned. Typically wages are very low, working conditions are very bad, written contracts are rarely concluded and there are unlikely to be any benefits, such as maternity leave, sick leave, annual leave or health insurance. Indeed, employers who express a preference for young women in factory jobs normally terminate employment once a worker gets married or becomes pregnant. Young women are also preferred because they are seen as docile and unlikely to take union action and agitate for improved wages and working conditions. The position of homeworkers in global commodity chains is even more precarious, as they are more isolated than factory workers and have a less tenuous link with their employer. Inevitably, homeworkers are paid less than those doing the same work in factory conditions. Indeed, many of those now engaged in home work used to work on better terms in factories, which laid them off in order to save costs. Thus, two patterns are observable in export-led manufacturing:

(a) Young women who have not worked before are now included in the labour force on terms which are not optimum, but possibly better than alternatives elsewhere in the domestic economy (Kabeer, 2000). In addition, the wage gap between women and men in export-oriented factories is narrower than in domestic production. For example, unskilled women workers in export-oriented garment factories in Bangladesh are paid almost the same ( 90 per cent) as unskilled men, compared with only 57 per cent of what men earn outside these factories (Joekes, 1999). Occupational discrimination still exists, however, as very few women are involved in supervisory and semi-skilled positions in which the wages are higher than for unskilled work, and gender wage gaps and occupational segregation have remained wide in many countries - indeed recent research shows that economies in Asia with the widest wage gaps grew most rapidly (Unni, 2002).

(b) Women who have been involved in factory production (with or without contracts and benefits) have now been excluded and do much the same work from their own homes on terms that are much worse than before. Without exception, home-based workers are paid less than informal factory workers and receive no benefits from their employers (who in any case often hide their links with such workers in a complex network of contractors and subcontractors), thus divorcing themselves from any responsibilities.

Several factors are now impacting on the situation of women workers in export-led industries. First, markets for labour-intensive products are becoming flooded and highly 
competitive. In this situation, one of two strategies seems to be adopted, neither of which is helpful in improving the terms of inclusion of women workers in the global economy. One strategy is for multinationals to try to maintain or increase their market share in existing industries by undercutting competitors, usually by cutting labour costs in the so-called "race to the bottom". This race is facilitated by the increased ability to substitute casual and homeworkers for permanent labour within the same country (flexiblization of labour) and by the easy mobility of capital across borders in search of the cheapest sources of labour. For example, when workers in footwear factories in Indonesia managed to raise their daily wage rate by about US\$I per day through union action, Nike simply switched its source of supply to Viet Nam to avoid the increased costs involved. Similarly, European buyers of ready-made garments have been switching from suppliers in Thailand to others in China and Viet Nam where labour costs are 30 per cent lower. This has led to decreases in pay and loss of work for both factory workers and homeworkers in the Thai garment industry (Lund and Nicholson, 2004). Thus, the very factors which led to women's "inclusion" in the global economy in the first place - unskilled, low wages, low productivity - are those which now have them trapped in downwardly mobile positions.

They are marginalized (or excluded) not so much by joblessness, as by types of work and working conditions that condemn them to low-wage, low productivity occupations which involve greater pressure and more drudgery as companies resort to "sweating" their labour force. This strategy is also detrimental for the companies that adopt it, as they become stuck in the trap of over-reliance on cheap labour, the exploitation of natural resources and generic commodity production, which can contribute to enduring impoverishment even as their business grows. Real wealth creation depends on companies developing the alliances, strategic thinking and innovation necessary to make the leap from easily imitated but unsustainable sources of competitive advantage to more complex and sustainable sources of competitive advantage (Forstater et al., 2002).

Regional trading agreements are adding to the movement of capital around the globe and the consequent loss of work and earning potential. For example, following the North American Free Trade Agreement (NAFTA), 150 factories were closed and 123,000 jobs lost in the apparel industry in the Caribbean as production moved to Mexico to take advantage of free imports to the United States market. The Asian apparel exporting countries may be the next to suffer from the indirect effects of NAFTA. For example, The Limited, a manufacturer of Victoria's Secret underwear, recently opened a plant in Mexico because, despite the fact that wages are three times higher in Mexico than in Sri Lanka, it is nonetheless more economical to produce in Mexico because of savings in time, transport costs and duties. Indeed, there has been a steady reduction in apparel imports from Asia to the United States, from 83 per cent of the total in 1980 to 41 per cent in 1996. Not only is it cheaper and quicker to operate within the Western Hemisphere, but it also allows United States textile manufacturers to supply the bulk of the fabric, something they cannot do with Asian suppliers (ILO, 1998).

The other strategy to address the problem of competition for labour-intensive products in export markets is to diversify into different types of products offering higher profits and less crowded markets. In countries where this is happening, the proportion of women employed in EPZs is falling as more men are recruited into new industries that are more technologically sophisticated and demand higher skill levels (which men are given greater opportunities to acquire). In Malaysia, for example, the proportion of women workers in EPZs fell from 75 per cent in 1980 to 54 per cent in 1990 (Joekes, 1999), while in Mexico the proportion of women in maquiladoras fell from 77 per cent in 1982 to 60 per cent in 1990 (Ghosh, 1995), and from 45 per cent in 1991 to 35 per cent in 1993 in the export sector as a whole (Ghiara, 1999). Thus, while skills were not needed to gain employment in the early stages of export-led industrialization, they are now becoming increasingly important in order to adapt to rapidly changing markets and are beginning to exclude 
women from the latest and more technology-intensive phase of globalization in which there is a switch from working "harder" to working "smarter".

Second, increased inclusion in the global economy has brought with it increased volatility and vulnerability. This was especially evident in the recent Asian financial crisis, which led to the closure of hundreds of export-linked factories financed by foreign direct and, especially, portfolio investment. In 1997, there was a net outflow of private funds of US $\$ 20$ billion from East and South-East Asia (with a massive impact on women in particular), compared with net inflows of US\$70 billion in 1995 and US\$80 billion in 1996 (Joekes, 1999), with unemployment rising in the countries concerned from 5.3 million in 1996 to 18 million in 1998 . The majority of those displaced were women, some of whom may well have found alternative work as homeworkers in subcontracting chains. However, many homeworkers also lost their source of income, as factories closed due to the crisis. In the Philippines, for example, over 200 garment factories closed in the first year of the crisis, with the result that homeworkers who used to supply these factories had to turn to self-employment, usually in street vending or even garbage recycling for very low profits, because they lacked access to the skills, technology and credit needed to establish more profitable enterprises (Carr, 1998).

Restructuring in response to crises, allied to the need to increase international competitiveness, has had similar effects in other parts of the world. In South Africa, for example, the restructuring process in labour-intensive industries such as garments is leading to the retrenchment of hundreds of women workers, an as yet unknown number of whom may find alternative work as homeworkers in the clothing industry. In addition, restructuring is shifting women who are already in the informal economy into lower and less secure segments of informal work: for instance, self-employed garment makers who lose their market niche are often forced to begin working under subcontracts as garment outworkers, while self-employed workers of various kinds may be forced to take up waste picking or garbage recycling to earn a livelihood (Chen et al., 2002).

Evidence suggests that, following a recession, women are less likely than men to regain work at the same level/on the same terms as before. For example, in Mexico, large numbers of women were laid off from all sectors during the 1995 crisis. During the recovery, they regained employment in small establishments in the informal economy, while men took over the formal employment previously occupied by women. Some 52 per cent of women in the textile and garment industry now work in enterprises with fewer than five workers, in jobs with no social benefits or security (Cardero et al., 2000).

Thus, in the case of export-oriented manufacturing, women - who were the early winners in the globalization process - are now beginning to lose out. They are losing ground in factory production, in terms of both jobs and work-related benefits, and are increasingly reliant on home-based work, which pays less, and/or on the most marginal of own account activities in the informal economy, such as vending.

Non-traditional agricultural exports (NTAEs). While Africa has largely been excluded from export-led industrialization, mainly because it is a greater abundance of land than of unskilled labour, it has become incorporated in global value chains of a different type, namely those involving non-traditional agricultural exports, such as fresh fruit, vegetables and cut flowers, aimed mainly at the European markets. Horticultural exports have doubled since 1980, and in 1996 they exceeded the region's exports for coffee, cotton and all other individual commodities other than cocoa (Lund and Nicholson, 2004). Again, women are those who are most involved in and affected by these chains and represent up to 90 per cent of the workforce of this fast growing sector (United Nations, 1999). In many ways, these chains replicate the labour-intensive manufacturing chains in Asia and Central America, with large corporations dominating the commodity chain, and with women 
working on large-scale "factory" farms at very low wages, in bad working conditions and without benefits of any sort. In practice, the terms of inclusion of women in these chains are perhaps worse than those of industrial workers for two reasons.

In the first place, work is seasonal, with the result that it is more difficult to earn a living wage. Research in South Africa shows that, while there are some permanent workers involved in these chains, they tend to be men ( 74 per cent), while women form the bulk of temporary or casual labourers ( 69 per cent) who have no contracts or benefits. Flexibility is partly a result of seasonality, but also reflects the labour practices adopted by employers in order to reduce their contractual commitment to workers, and as women comprise the majority of flexible workers they are relatively more "excluded" than male workers. There is also a trend towards the use of contract labour, with contractors employing labour that is then provided on a third party basis to producers. The labour contractor is responsible for the employment conditions and pay of the workers, removing this responsibility from the producers themselves. This reflects a further increase in the "flexibilization" of employment and the vulnerability and insecurity of workers. It also represents a challenge for the extension of social protection and other benefits in the sector, as the employer (the contractor) is more difficult to trace and monitor than a more stationary employer (the producer).

Secondly, the health risks involved in horticulture production are higher than in garments and other labour-intensive manufacturing industries. These include: (a) the use of toxic products by temporary workers without adequate training and protective clothing, leading to allergies, eye soreness, skin problems and higher rates of malformation among newly born babies; (b) stomach problems and bladder infections due to lack of drinking water and toilet facilities; and (c) muscular pain and discomfort, lumbago and rheumatism because of the physical demands and long hours of work, often in damp and cold conditions (Lund and Nicholson, 2004). Consumer pressure in the North is forcing supermarkets to buy from producers which take measures to reduce health risks and are more environmentally sound, but this, in part, is leading to more vertically integrated commodity chains in which northern supermarkets are increasingly involved in every stage of the production process, with direct consequences for the inclusion and exclusion of actors and the division of functions within the chain (Dolan and Tewari, 2001; Barndt, 1999)

NTAEs are also very popular in Latin America. Between 1985 and 1992, the growth rate in the production of fruit, vegetables and flowers was 17.2 per cent per annum in Central America and 48 per cent per annum in South America (excluding Brazil). Employment patterns are similar to those in Africa. For example, in Chile, where fruit exports expanded from 340,000 tonnes in 1982 to 1.2 million tonnes in 1994 , only 5 per cent of the permanent workforce (but 52 per cent of temporary workers) are women. The expansion of the industry, combined with consumer pressure in the North, has resulted in many local farmers being displaced from their land as northern supermarkets seek to ensure that they can guarantee the standards demanded by their customers. Displaced smallholders now make up some of the 300,000 temporary workforce involved in NTAEs (Barrientos et al., 1999)

The export of NTAEs from Asia is also beginning to take hold and at the global level edible horticultural export products now exceed trade in cereals. It is thus an important and growing part of the global economy and one in which there are many implications for the social exclusion/inclusion of informal workers and producers in the South. This also applies to informal women workers in the North. Studies which trace the export of fruits from Chile to the United States (Barrientos et al., 1999) and of tomatoes from Mexico to Canada (Barndt, 1999) both point out that women who work in northern supermarkets are also subject to part-time work at short notice, have low pay and lack work benefits. 
Export of services. While globalization is not a new phenomenon, the distinguishing feature of current globalization is that countries have become increasingly connected through trade in digitized information. With the digitization of information, it has become possible, and generally cost-effective, to transfer information processing work, both in manufacturing and in services, to offices and work units that are remote from main premises, within and across national boundaries. In some developing countries, women have become the major recipients of this globally distributed work (Mitter, 2003).

Again, this type of global system replicates that of export-led manufacturing in that large numbers of young women are being recruited by emerging institutions of the digital economy, such as call centres, thereby providing new opportunities for inclusion, but on terms which discourage long-term, permanent contracts or unionization. Although more skills are required in this sector than in manufacturing and NTAEs, women still tend to be clustered in the low-skilled end of the hierarchy, with few prospects of career progression. They are more likely to be employed in data entry and customer care centres than in the software sector. Data entry has looked promising for women to date (for example, 100 per cent of workers in "digiports" in Jamaica are women, and the majority of data entry jobs for airlines, banking and insurance companies in India are occupied by women). But technological changes could lead to redundancies if women do not have the necessary training and skills to adapt. In addition, data entry is also becoming more footloose. For example, there are indications of data entry work moving from India (with relatively high wages of US $\$ 1,250$ per annum) to countries in Africa such as Ghana (with relatively low wages of US $\$ 480$ per annum). As with other types of labour-intensive work in which women predominate, concerns about long-term health risks have also led to data entry firms being classified as "electronic sweatshops" (Mitter, 2003).

A more recent development in the digitized service sector has been that of customer care services, which provide white collar work for women and men with modest educational levels. The services are normally provided for foreign companies, such as British Airways and American Express, with women (normally unmarried and between 20-25 years of age) representing between 40 and 70 per cent of the workforce. Pay levels in this type of work are higher than most other export sectors, but the work is hard and often monotonous. The problems faced include the need for workers to pretend that they are from and based in Europe or America and to speak with the relevant accent. This leads to what is being termed "cultural schizophrenia". In addition, stress levels are high, both as a result of the highly competitive environment, in which incentives are offered for top performers, and the need for employees to deal civilly with their clients, many of whom tend to be abusive and even hysterical. As a result, the "burn out" factor in this work is very high. However, most women see this as an interlude between school and marriage and tend to be unconcerned about length of employment, contracts, benefits and career progression (Mitter, 2003).

\section{B. Barriers to inclusion in global production systems}

In economic terms, globalization has led to winners and losers, according to who you are, where you are and how you make your living. As seen in the previous section, women in developing countries have been able to benefit to some extent from inclusion as paid workers in the global economy, although the quality of the work has been questionable and the benefits for individual women are often short-lived. Also, as globalization evolves, the prospects for women workers as a whole are in jeopardy because their lack of skills, in relation to those of men, restricts their ability to adapt to changing conditions on the labour market and to move into more technologically advanced types of employment. 
Many of the women who enter paid work in export-oriented industries and global value chains are drawn from the pool of women who earn their living as own account workers. As seen above, when women lose either factory work or home work in export sectors, they often have little alternative but to return to self-employment.

With the exception of crafts, own account activities and micro-enterprises have tended to be linked to local and domestic markets. However, globalization is now opening up new opportunities for the self-employed to be directly involved in export markets if they have the ways and means to take advantage of these opportunities.

Unfortunately, a great many barriers constrain own account workers from developing links with global markets, and women generally face more constraints in this respect than men. For the main part, these barriers relate to exclusion from factor markets and lack of access to land, credit, training, technology, infrastructure, information on markets and prices and other economic inputs that are necessary for integration into the global economy. Other barriers include a lack of organization into cooperatives or associations, the lack of voice and representation and, especially in the case of women, lack of mobility (cultural restrictions) and time (domestic responsibilities). The absence of a conducive policy and regulatory environment for micro-enterprises can also exclude entry to export markets. All of these apply to the agricultural, manufacturing and service sectors (including businesses related to information and communication technologies - ICT - such as telekiosk businesses). They constrain those wishing to increase productivity/quality to meet higher standards in export markets, diversify into new products in order to enter export markets and set up an export business for the first time.

Two trends are observable in the case of the self-employed in the informal economy. First, many are being absorbed into global production systems, often without their consent/knowledge and/or against their will, and on terms that are not entirely favourable to them. This is happening, for example, with many forest workers who earn their living from gathering and selling non-timber forest products (NTFPs), such as medicinal plants, mushrooms, nuts and spices. By definition, these workers live in remote areas and can only link with markets, even domestic ones, through a chain of middlemen. As the demand for such products is growing in global markets (there are now 150 NTFPs of major significance in international trade), there is increasing interest on the part of foreign companies in commercializing these commodities. For example, in the case of shea nuts in West Africa, there is a growing and profitable market for processed shea butter in Europe, North America and Japan for use in cosmetics and, more recently, in chocolate manufacture. While demand for shea butter is growing in the North, with a consequent rise in the final price for shea butter in Northern markets, women who collect shea nuts are totally unaware of this trend and continue to sell to their existing brokers/middlemen, who then feed the nuts into the ever more profitable global value chain, as well as continuing to supply domestic and regional markets. Thus, women shea nut collectors are now integrated into global value chains, but without any knowledge of this and without any means of exploiting more profitable markets to their own advantage (Carr and Chen, 2002).

Second, some of the self-employed have been able to link with global markets on their own terms through a range of strategies (including the formation of associations and cooperatives), often with the assistance of local and international NGOs, government departments and local social entrepreneurs. For example, artisanal embroidery workers who are members of the Self-Employed Women's Association (SEWA) in India are being enabled to sell their produce in North America and Europe through the formation of producer and marketing cooperatives and the establishment of their own Trade Facilitation Centre, which undertakes all the necessary international market research and international marketing activities on their behalf (Commonwealth Secretariat, 2002). In many countries, associations and cooperatives of smallholders have opened up sustainable channels for 
their commodities to northern markets. These include the coffee cooperatives in Colombia. And in others, social entrepreneurs have established export businesses which include smallholders or artisans as partners. For example, Fruits of the Nile in Uganda enables over 100 women farmers to export dried fruit to the United Kingdom. These women retain their independence, while at the same time earning twice the income that they could make from sales of fresh fruit in the domestic market (ACGD/WIEGO, 2003)

These examples differ from both the shea nut case and the cases of the paid workers mentioned above in that they do not deprive the workers of their independence. They leave producers in control of decisions concerning how, where and when they undertake their work. Enabling groups of own account workers to organize in ways which assist them to overcome barriers to their inclusion in the global economy is obviously an important strategy. However, the measures taken by own account workers/the self-employed to overcome exclusion sometimes result in turn in the exclusion of other equally vulnerable groups. For example, in Cameroon, where various voluntary associations have been formed by different groups to act as informal social security systems and/or parallel financial systems to official banks, one ethnic group, the Bamileke, which have a more developed associational life, have been able to use tontines (informal credit associations) in advancing their business interests and monopolizing lucrative trading activities to the exclusion of other vulnerable groups (Rogers et al., 1995).

\section{New forms of exclusion in domestic production systems following the liberalization of trade and investment}

Finally, there are many cases in which globalization is resulting in the destruction of earnings opportunities for informal workers/producers and/or the substitution of existing forms of work and employment by less favourable ones. These include: destruction of employment/work opportunities through the entry of foreign companies using more advanced technologies; destruction of local enterprises and jobs as a result of the influx of cheap imports; and destruction of local enterprises/jobs and/or loss of preferred types of work and status through raw materials being taken over by foreign companies.

Imported technologies. A good example of how foreign companies, enabled by the liberalization of trade and investment and using advanced technologies, are destroying local jobs is that of the construction industry in India. Under the prevailing World Trade Organization (WTO) regime, the essential requirement of global tendering has facilitated the entry of many large international companies into India. The presence of some of these companies is increasingly visible in many of the infrastructure development projects being undertaken with government funding, as well as under bilateral/multilateral assistance arrangements. With the increased mechanization involved, there is a massive displacement of the labour involved in all construction operations, and particularly those in which women have traditionally been deployed, such as soil digging and brick carrying. The Indian Government is responding by assisting Indian companies to compete by upgrading their own technological capabilities, a move which will lead to still further labour displacement through mechanization. In general, women are likely to lose more jobs than men, and the jobs created for the operation of new technologies are almost certain to go to men rather than women. In the absence of training for women in construction skills, such as masonry, for which there is a growing demand, the net result of a more open economy will be a massive loss of work opportunities (Jhabvala and Kanbur, 2002; Chatterjee, Chen and Unni, forthcoming).

There are similar changes in employment patterns in other sectors in India and elsewhere in South Asia. Thus, when chemical spraying replaces hand weeding (a female 
occupation), the spraying is most likely to be performed by men. Mechanized rice mills are operated mainly by men, while women who traditionally used manual methods for husking paddy lose their means of livelihood. In the textile sector in India, handloom weavers are being rapidly replaced by power loom weavers, and power loom weavers with lower quality machines are being replaced by those with better quality machines. In the food processing sector, multinationals with huge investments and state-of-the-art technology are replacing small units which were labour-intensive and employed thousands of women workers (National Commission on Labour, 2001). And in the coir industry in Sri Lanka, export promotion policies have led to a shift in the type and ownership of units and in the supply of coconut husks to mechanized units owned by men with access to credit and away from manual units operated by women with little access to credit (Bajaj, 200I).

Competition from imports. Oilseeds and the production of cooking oils provide a good example of how the opening of the economy is leading to the closure of local enterprises and the loss of informal jobs through competition from imports. In most African countries, small-scale oil processing plants have closed owing to competition from imports of cooking oil from South-East Asia (ACGD/WIEGO, 2002). Similarly, in India, 3 million jobs have been lost as a result of the closure of small oil mills producing mustard seed oil following the influx of cheap soya based cooking oil from North and South America. In addition to the destruction of jobs, this latter development also prevents consumers from consuming the cooking oil of their choice (Shiva, 2000).

Other cases of destruction of informal enterprises and jobs and/or lowering of prices for domestic commodities include: the reduction in maize production in Mexico following NAFTA, which is estimated to result in the loss of almost one million livelihoods (Madeley, 2000); and the fall in prices paid to women gum collectors in India as a result of large-scale imports of gum from Sudan. In the latter case, the problem has been compounded by the fact that gum collectors are required by law to sell to the Forestry Department and are prevented from selling to private traders who pay much higher prices (Jhabvala and Kanbur, 2002).

A variation on the above examples is the loss of jobs in local retail businesses with the arrival of foreign superstores. For example, one effect of NAFTA has been the rapid proliferation in Mexico of discount stores from the United States, such as Kmart and WalMart, with resulting pressures on local business (Beneria and Lind, 1995). Supermarkets are also spreading in many other parts of the world. For example in southern and eastern Africa, they have already proliferated beyond middle-class big city markets into smaller towns and poorer areas, where they are having an impact not only on local retailers, but also on small food producers, who have to make investments and adopt new practices if they are to avoid exclusion from markets that are increasingly dominated by supermarkets (Weatherspoon and Reardon, 2003).

Control of raw materials/natural resources. In many countries, governments have actively encouraged foreign investment in the processing of local raw materials/natural resources for export in order to earn foreign exchange. This has normally been done without any consideration of the impact on the domestic economy and on the thousands of informal enterprises, smallholders and workers who stand to be affected.

For example, under the pressure to cultivate cash crops for export, many States in India have allowed private corporations to acquire hundreds of acres of land. The State of Maharashtra has exempted horticulture projects from its land ceiling legislation; and Madhya Pradesh is offering land to private industry on long-term leases. In Andra Pradesh and Tamil Nadu, private corporations are today allowed to acquire over 300 acres of land to raise shrimps for export. A large percentage of agricultural production on these lands 
will go towards supplying the burgeoning food processing industry, in which many transnational corporations are involved (Shiva, 2000).

While the commodities involved, including flowers, fruit and shrimps, will undoubtedly bring in foreign exchange, thousands of jobs will be destroyed and many smallholders will be forced to sell their land and become casual day labourers, with a consequent loss of independence and status. According to one estimate, shrimp cultivation in India destroys 15 jobs for each job it creates (Shiva, 2000). There are also accounts of small holders in Thailand and elsewhere who have been forced through declining farm incomes to become contract workers for multinationals producing baby corn and other export crops. Initially, the companies brought in seeds and fertilizers and bought back produce at guaranteed prices, and farmers could survive on two crops a year. However, over time, yields started to decrease and it became necessary to grow six crops a year, with resulting damage to the soil, so that farmers were no longer able to afford the increased expenditure on the required seeds and fertilizers. In cases such as these, multinationals normally simply move on to other countries where more farmers are encouraged to start producing for export markets with the same destructive consequences (Shiva, 2000; Thai Development Newsletter, 1998).

Similarly, in Africa, several governments have encouraged foreign investment in fish processing for export markets. For example, through the liberalization of trade and investment policies in the three countries surrounding Lake Victoria, 50 modern capitalintensive fish processing factories have been established, which export fish to Europe and Japan. This has resulted in thousands of women losing their jobs in the smoking and sale of fish in local markets, and has also meant that there is little or no fish available to eat locally, with disastrous effects in terms of malnutrition among children (IUCN, 1997). A similar situation is to be found in Senegal, where the presence of European fishing fleets and processing factories has turned previously own account women workers into dependent day labourers, who must often wait up to two or three days at the factory gates to obtain work.

In all of the above cases, informal workers and producers, although they still have some means of livelihood, become newly excluded from their preferred types of work/employment as a result of increased globalization.

\section{Synthesis and policy implications}

This section is divided into two parts. In the first part, some general conclusions are drawn from the examples cited in the previous section on the articulation between globalization, social exclusion and work in the developing world, with special emphasis on the informal economy and gender. In the second part, some policy implications are identified for what should be done at the local, national and international levels to promote social inclusion within the context of increased economic globalization, including the gender issues involved. A few examples are also provided of what is being done to promote social inclusion on more favourable terms.

\section{A. General conclusions regarding social exclusion in the realm of work}

Important contextual differences between developing and developed countries. In the past, most countries in Europe and North America enjoyed an era of full (or near full) employment and a welfare state. In recent years, however, many have experienced an evolution of the labour market towards greater flexibility and a crisis of the welfare state. 
The rise in unemployment and in precarious jobs, seen as two dimensions of social exclusion, is blamed in part on the liberalization of trade. In contrast, most developing countries have never enjoyed full employment or a welfare state. Historically, in developing countries, social exclusion in the realm of work has primarily taken the form of long-term employment in the informal economy: both self-employment and paid employment. More recently, there has been an increase in precarious paid jobs due, variously, to trade liberalization, other economic reforms and the strategies of formal businesses.

The focus of this paper has been as much on the terms of inclusion as on the forms of exclusion in the realm of work in developing countries. This is because the concept of unemployment does not "fit" the reality of much of the developing world. Moreover, globalization is widely credited with creating employment in developing countries: so the real question becomes "What type of jobs? On what terms?" For these reasons, the nature of the debate around social exclusion/inclusion in developing countries is somewhat different from the debate in developed countries and focuses more on: the terms of employment, not unemployment; precarious forms of self-employment, not just paid work; and exclusion from all factor markets, not just labour markets.

Hierarchy of exclusionary processes. Based on the examples cited in Section 2, we do not see social exclusion and inclusion as a dichotomy. This is because there are many forms of exclusion and inclusion which often operate simultaneously. Also, we do not see the various forms of exclusion and inclusion as simply points along a continuum between pure exclusion at one end and pure inclusion on the other. Rather, we conceptualize the various forms of social exclusion/inclusion as a hierarchy that operates simultaneously and in different ways in relation to individual workers or producers. Also, we see this hierarchy of social exclusion as being structured by dominant institutions and players, both national and supranational, who variously govern the overarching policy environment, the specific economic system (zone, chain, subsector) within which the workforce operates and the underlying social structures that determine who owns what and who does what.

To understand how the hierarchy of social exclusion/inclusion works in the realm of work, we need to be able to answer three questions: namely, exclusion or inclusion from what, how and by whom. In the realm of work, the answers to these questions can be depicted as follows:

\begin{tabular}{|l|l|r|}
\hline \multicolumn{1}{|c|}{ From What? } & \multicolumn{1}{|c|}{ How? } & $\begin{array}{r}\text { By whom? } \\
\text { market transactions } \\
\text { policies/laws } \\
\text { social norms } \\
\text { Land } \\
\text { housing } \\
\text { other productive assets } \\
\text { creditsavings } \\
\text { secure jobs/productive work } \\
\text { income } \\
\text { worker rights/benefits }\end{array}$ \\
\hline rules of the game"
\end{tabular}

What it is intended to suggest through this figure is that dominant players (right column) determine who is excluded/included from economic resources (left column) through their influence over mainstream institutions, social norms, market transactions and policies/legislation (middle column). In other words, the structures, institutions and rules in 
the middle column are seen as being socially determined by the dominant players in the right column. The mode of their control, as well as the norms or rules that they determine, may be formal or informal, or some mix of the two.

In terms of gender, what we want to suggest through this figure is that dominant players at the community and household levels determine the social norms regarding gender roles and relationships. Equally importantly, these gender norms are reflected not only in the intra-household allocation of economic resources, but also in market segmentation and policy biases.

In summary, our overall analysis would suggest the following:

- processes of exclusion/inclusion from desired goods operate through markets and policies/laws, which are in turn governed by powerful agents and mainstream institutions;

- markets and policies/laws are "socially embedded", that is they are designed or governed by powerful agents through various institutions, both formal/informal and local/national/international;

- exclusion/inclusion are caused not only by the workings of state agents/institutions, but also those of other institutions/agents (private sector, civil society, family/community);

- exclusion/inclusion are caused by the workings of the State, market, civil society, family/community agents/institutions not only at the local and national levels, but also at the international level;

- processes of exclusion/inclusion do not operate just in labour markets or in terms of social security, as originally conceived in Europe, but also in other factor markets and under other social, economic and political policies/laws/regulations.

Specific processes of exchusion/inclusion within production systems. To understand how all of this operates within specific production systems, it is necessary to be able to answer a more precise set of questions, as follows:

- input-output structure and associated economic relationships: who is doing what for whom? Under what type of contractual arrangement?

- geographical location(s) and spatial organization: where is production/distribution located? How is it structured or organized?

- governance structure and power relationships of the system: who is "driving" specific chains or zones?

- regulatory influences: how are these systems regulated? By whom? At the local, national and international levels?

In this paper, we have explored three different patterns of social exclusion/inclusion in the realm of work associated with global integration:

- Pattern No. 1. Cases in which export-led growth and development have resulted in increased inclusion of workers in the global economy, but on questionable/undesirable terms and with uncertain sustainability. In terms of inputoutput structures, most global production systems - both chains and zones - have core workers (hired directly) and peripheral workers (hired indirectly through subcontracting arrangements)

In many global value chains, core functions are retained in core locations, while peripheral functions are subcontracted to multiple peripheral locations, further reinforcing the core-peripheral distinction between workers. In many export 
processing zones, even core workers are hired under insecure contracts with few nonwage benefits.

In terms of geographical location and spatial organization, most zones have historically been specially designated as enclaves. In recent years, some countries have expanded the geographical boundaries of the zone to include entire cities (for example, China) or the entire country (as in the cases of Mauritius and Sri Lanka). But whatever the geographical boundary, zones are typically limited to one country. In contrast, the locus of production in global value chains is by definition dispersed across more than one country. This territorial dimension reflects the fact that zones are set up by governments, while chains are driven by foreign, if not multinational, companies. In both systems, the lead firms may chose to change the location or organization of production, depending on the comparative advantage of different locations, the seasonal volume of demand or other economic considerations.

In terms of internal governance and external regulation, zones and chains are quite different. This is because zones are typically set up and driven by governments, albeit in the interest of attracting foreign direct investment, while chains tend to be formed and driven by private companies. Whereas, by definition, the productive workforce is removed from the locus of control and power in most global value chains, the distance is typically greater in buyer-driven chains than in producer-driven chains. Of course, in real life, this chain versus zone distinction does not hold neatly. This is because most zone enterprises operate in one or more global value chains. Moreover, many global value chains include firms that operate out of export processing zones. But in terms of governance, except for zones that are set up by and supply a single foreign firm, export processing zones have a different governance and incentive structure than global value chains.

- Pattern No. 2. Cases in which barriers to entry have prevented the self-employed/own account workers from taking advantage of the new economic opportunities arising from the liberalization of trade and investment. In such cases, traditionally self-employed entrepreneurs/own account workers are not able to enter or compete in or with the export-oriented input-output processes outlined above. They are further disadvantaged when the lead firms in particular export sectors change the location or organization of production. If they are able to secure a foothold as a supplier or contractor in an export chain, they are very likely to be excluded from the internal governance processes of the chain. Furthermore, external regulation of the chain is more likely to focus on foreign investors within the chain than on domestic producers for the chain, thereby excluding domestic firms (especially very small ones) from the various incentives and exemptions offered to foreign firms.

- Pattern No. 3. Cases in which the liberalization of trade and investment, especially in accordance with the "rules of the game" set by multinational corporations and the international financial institutions, have resulted in the destruction of domestic enterprises or paid jobs through: the flooding of the market with cheap imports/ services: competition on unequal terms for local natural resources; and changes in the technologies and skills required. In such cases, shifts in domestic subsectors, driven by increased imports and/or foreign investment, are leading to exclusion from paid jobs (due to changes in the required skills and technology) and/or exclusion from selfemployment (due to changes in technology, competition for raw materials or competition on product markets). These processes are associated with shifts in the location of production (foreign firms entering local raw material and labour markets) and the location of distribution (foreign products flooding local product markets). In terms of internal governance, these shifts are often accompanied by a breakdown in traditional forms of governance, both informal and formal, as foreign firms begin to compete in domestic sectors. The new forms of internal governance that emerge are often biased towards foreign firms. Similarly, new forms of external regulation are 
often biased towards foreign firms, or at least large firms. For example, the costs of joining the new board that governs the newly-liberalized construction industry in India are so high that few domestic firms, other than the very largest, are able to join (Jhabvala and Kanbur, 2002)

\section{B. Policy recommendations}

As the above analysis suggests, we see the social outcomes of global integration as not somehow being the "natural" outcomes of market forces, but rather as "political" outcomes determined by the choices, in terms of policies, technology and market transactions, made by dominant players and institutions. This gives us reason for optimism. We believe it is possible to change policies if it is understood how these dominant institutions and processes work. Admittedly, the social outcomes of global integration - and global integration itself - are also driven by information communication technology, which may be harder to harness

\section{Specific policy recommendations}

If an understanding is reached of how social exclusion/inclusion works in different patterns of global integration, it should be possible to promote greater or more favourable inclusion. Below, we summarize our policy recommendations to address the three patterns of social exclusion/inclusion detailed above, with specific examples for each.

(a) Pattern No. I. For paid workers in global production systems, the key policy instruments would be to extend labour standards and social protection measures to cover all workers in the system, both formal and informal. This should be done by promoting a context specific mix of collective bargaining agreements, national labour legislation and international standards, including ILO Conventions and voluntary codes of conduct. International labour standards, and related norms and regulatory frameworks, should be promoted to help improve and reinforce, but not replace, national labour legislation. To ensure that both international standards and local legislation are translated into practice, collective bargaining arrangements for all workers, formal and informal, should be promoted

(b) Pattern No. 2. For self-employed entrepreneurs/own account workers trying to compete in global markets, the key policy instrument would be to offer financial services, business development services and incentive packages to promote their access to and competitiveness in global markets/production systems. These services should ideally be offered through some combination of private sector and non-governmental organizations, with government supervision, subsidies and other incentives, or through cross-sector collaboration.

(c) Pattern No. 3. For self-employed entrepreneurs/own account workers trying to compete with foreign companies for raw materials, the key policy instruments would be supportive trade and price policies that take into account the activities and needs of micro-enterprises and own account operations. For paid workers trying to compete in domestic labour markets, the key policy instruments would be skills upgrading and placement services. Again, these services should be provided by an appropriate context specific combination of private sector and non-governmental organizations, with government supervision and support, or through cross-sector collaboration 
In addition to these pattern specific mixes of policy instruments, two broad areas of reform are needed to promote social inclusion in the realm of work. The first is to reduce four types of biases in the policy, regulatory and institutional environment:

(a) Biases against labour (which privilege capital): most notably, in the context of globalization, these biases allow companies to move the site of production quickly and easily across borders without obligations relating to labour;

(b) Biases against the informal workforce (which privilege the formal workforce): in labour law, labourforce statistics and the international labour movement;

(c) Biases against micro-businesses and own account activities (which privilege small and, in particular. large businesses): most notably, in trade promotion, including incentive packages, and in business development services; and

Biases against women (privileging men) which compound each of the other biases: reflected not only in gender relations, but also in market relations and labour market segmentation.

Correcting these systemic biases will require political will and sustained effort over time. In the interests of showing what is possible, examples are provided below of what has been, or is being done to address each type of bias.

(a) Bias No. 1. To reduce the ability of companies to shift the site of production quickly and easily across national borders, without consideration for employees/workers who lose jobs/work orders in the process, various measures have been proposed, although they are not yet widely implemented, including: forcing companies, through non-legal or legal measures, to provide severance notice and pay and/or encouraging host governments to impose a tax when companies withdraw investment to cover the severance pay due.

(b) Bias No. 2. The conclusions of both the International Labour Conference (ILC) general discussions on the informal economy in 2002 and on the scope of the employment relationship in 2003 provide guidelines and a mandate for reducing the bias against the informal workforce in labour law, labour statistics and within the international labour movement. For instance, the employment-based definition (and statistical framework) of the informal economy endorsed in the conclusions to the general discussion on the informal economy need to be adopted officially by the International Conference of Labour Statisticians (ICLS). Also, building on the conclusions of the 2003 general discussion on the scope of the employment relationship, national and international legal initiatives should be encouraged to: prevent companies from disguising the employment relationship; and clarify and extend the scope of labour law.

(c) Bias No. 3. A recent study commissioned by the City Council of Durban, South Africa, highlights the existing bias towards big business in the incentive packages, trade promotion and business development services offered by the city (Budlender, 2000). The alternative approach, which the Durban City Council is now trying to promote, is to explicitly and systematically target incentive packages, trade promotion and business development services at microbusinesses, especially those run by women and/or by persons from ethnic minority groups. Alternative trading organizations should be supported, especially those, such as Oxfam's Fair Trade, which seek to ensure that their suppliers comply with ethical trading principles (Wilshaw, 2002). Moreover, pilot efforts to develop mainstream trading links for groups of women informal producers, such as those being promoted by SEWA in collaboration with both the 
World Bank and the Women in Informal Employment Globalizing and Organizing (WIEGO) global network, should be supported.

(d) Bias No. 4. Women workers should be consulted and, better still, invited to join/participate in trade union organizing, collective bargaining agreements, negotiations relating to local labour legislation and the formulation of international standards, including ILO Conventions and codes of conduct, to ensure that their needs are reflected and addressed.

Many women's organizations, some set up by women from the formal trade union movement, have been founded to focus on the promotion and defence of women workers. Many of these are membership-based organizations of women workers or seek to promote membership-based organizations of women workers. And many seek to reflect the genderspecific interests or concerns of women workers in the formulation of national labour legislation and international or national labour standards. For example, SEWA served as a member of a recent National Commission on Labour which drafted umbrella legislation for the informal or unorganized workforce in India. The Movimiento de Mujeres Trabajadores y Desempleadas Maria Elena Cudara (MEC), a national autonomous women's organization in Nicaragua, drafted a national Ethical Code that was endorsed by the Ministry of Labour, adopted as a Ministerial Decree and subsequently signed by employers in the free trade zone in Managua (Prieto et al., 2002). The MEC has also been active in the Central American Network of Women in Solidarity with Maquila Workers, which seeks to ensure that women workers are not marginalized in the formulation and discussion of codes of conduct.

The second broad area of reform is the reform of institutions that coordinate or govern market transactions and global integration by increasing the voice of low-income workers and producers in these institutions. These institutions would include the market institutions, both formal and informal, that govern and regulate global value chains, export processing zones and domestic economic subsectors. They would include the intergovernmental institutions, both the ILO and the WTO, that design international labour standards and trade policies, as well as the institutions (companies, business associations and multi-stakeholder alliances) that develop voluntary codes of conduct. To date, with a few notable exceptions, the so-called "interests" of informal workers have been "represented" in these institutions (if at all) either by governments, formal trade unions or non-governmental organizations (NGOs), but not by the representatives of membershipbased organizations of informal workers and producers. In the debate on codes of conduct, for instance, there is growing recognition that the perspective of workers from the South, especially women workers, has not been widely reflected in the formulation, implementation, monitoring or verification of the codes (Jenkins et al., 2002).

Finally, to make mainstream policies, regulations and institutions accountable, the sine qua non is the promotion and strengthening of membership-based organizations of informal workers and producers. Unless and until informal workers and producers are effectively organized and gain a voice or representation in mainstream institutions, they will continue to be excluded from global integration and/or included on unfavourable terms.

It has been assumed until recently that workers in the informal economy are by definition unorganized. However, recent evidence suggests that the informal workforce has been and is being organized, both by formal trade unions, alternative trade unions and pro-labour NGOs. But to date few genuine membership-based organizations of informal workers have been recognized as such by national trade union centres or the international trade union movement. 
The example of the Self-Employed Women's Association (SEWA) in India is a prime case in point. Founded by a trade union lawyer and organizer in 1972 as a trade union of women workers in the informal economy, it took SEWA over two years to be registered as a trade union, over ten years to be recognized by some of the International Trade Secretariats (ITS), over 20 years to be invited to join the National Labour Congress of India and 30 years to be invited to be an official member of the Worker delegation from India to the International Labour Conference. In trying to gain official recognition within the international labour movement, SEWA has served as an inspiration for three other international movements: the women's movement, the micro-finance movement and a growing movement of informal workers and producers.

Since the early 1990s, the international alliance known as HomeNet has been working through its regional and national branches, which are comprised of both membership-based organizations and labour-related and/or women's NGOs, to strengthen membership-based organizations of industrial homeworkers and other home-based workers and to promote their "visibility and voice". In the mid-1990s, HomeNet and its member organizations played a major role in the campaign leading to the adoption in 1996 of the ILO Home Work Convention (No. 177). More recently, HomeNet has been working with the Ethical Trading Initiative in the United Kingdom and the Clean Clothes Campaign to see whether (and how) the scope and content of codes of conduct, especially in the garment sector, can be expanded to cover and protect industrial homeworkers and other home-based workers (Brill, 2002). Similarly, the recently-established international alliance of street vendors known as StreetNet, which includes membership-based organizations of street vendors as well as national associations of street vendor organizations, is seeking to strengthen membership-based organizations of street vendors and to help them negotiate with the institutions that regulate street vending, such as the police, municipal governments and market associations, and to increase their "voice" or representation in relevant policymaking institutions.

In sum, there is no single "magic bullet", or even a shortlist of "magic bullets", that might adequately address the complex mix of exclusion from and inclusion, on less than favourable terms, in the work/employment opportunities generated by global integration. For the self-employed, a mix of promotional measures is required to increase their global competitiveness, ranging from trade policies to business development services. For paid workers, a mix of protective measures is needed to decrease their disadvantages and vulnerabilities in the global labour market, including labour standards, labour legislation, collective bargaining agreements and workforce development. In addition to these specific measures, two broad areas of reform are necessary: policy and regulatory reforms to correct for systemic biases against labour in general, informal labour in particular and women workers of all kinds; and institutional reforms to strengthen organizations of informal workers/producers and to promote their representation in relevant policy formulation and rule-setting institutions. There is a clear role for international organizations, and global governance more broadly, in creating the global norms and frameworks for ensuring that these measures and reforms are implemented at the national and local levels. Most critically, international organizations and global networks or alliances must take the lead in promoting global economic democracy by strengthening the representation of membership-based organizations of informal workers, especially women, in their deliberations 


\section{Closing observations: Social exclusion and poverty}

From our perspective, social exclusion and inclusion are seen as analytical concepts related to causal mechanisms or processes, not outputs or conditions. In other words, unfavourable patterns of social exclusion/inclusion are seen as a cause of income poverty and other manifestations of poverty, not as a parallel measure or characterization of deprivation or disadvantage. Indeed, it is our premise that exclusion from, and even more so, unfavourable terms of inclusion in various aspects of work and employment, are important drivers of poverty and inequality. At the same time, we recognize that there are feedback loops through which the resulting patterns of poverty/inequality can reinforce the processes of exclusion/inclusion. As noted at the outset, we did not have the time or resources in writing this paper to assemble available evidence to test our assumption. But it is hoped that the examples and analysis provided here will stimulate and inform future research on the links between globalization, poverty, social exclusion and work. 



\section{Bibliography}

ACGD/WIEGO. 2002. Report of the African Regional Workshop on Food Processing and Minor Forest Product Global Value Chains. Kampala, Uganda. December. African Centre for Gender and Development/Women in Informal Employment Globalizing and Organizing

Allaert, B. 2001. International trade and gender inequality: A gender analysis of the trade agreements between the European Union and Latin America. Brussels, Women in Development Europe (WIDE)

Thai Development Newsletter. 1998. Impacts of economic meltdown in the villages. No 34, JanuaryJune

Bajaj, M. 2001. Invisible workers, visible contributions: A study of homebased women workers in five sectors across South Asia. Background Paper for Regional Policy Seminar. Nepal, October.

Barndt, D. (ed.). 1999. Women working in the NAFTA food chain: Women. food and globalization. Toronto, Second Story Press

Barrientos, S., with Bee, A., Matear, A., Vogel, I. And Kay, C. 1999. Women and agribusiness: Working miracles in the Chilean fruit export sector. London, Macmillan.

Beall, J. and Clert. C. 2000. Globalization and social exchusion: Implications for urban social policy. Paper prepared for "African Families II: Macroeconomics". World Bank.

Beneria, L. and Lind, A. 1995. Engendering international trade: Concepts, policy and actors. Paper prepared for GSD/IFIAS and UNIFEM.

Bhattacharya, D. 1999. "The post-MFA challenges to the Bangladesh textile and clothing sector", in Trade, sustainable development and gender. New York and Geneva, UNCTAD

Blackman, R. and Litchfield, J. 2001. Globalisation and poverty. Poverty Research Unit Notes No. 2. Sussex.

Brill, L. 2002. "Can codes of conduct help home-based workers?" in Jenkins, R. Pearson, R. and Seyfang $\mathrm{G}$. (eds.), Corporate responsibility and labour rights: Codes of conduct in the global economy. London and Sterling, Earthscan.

Budlender, D. 2000. Budgets and the informal economy. Study 4, research report for the Technical Task Team for the Informal Economy, Durban North and South Central Local Councils, South Africa.

Campbell, D. and Parisotto, A. 1995. The global value chain concept in relation to the IILS programme at work. Paper presented at the "Informal Workshop on the International Organization of Production: A 'Commodity Chains' Approach," Geneva, 20-21 March.

Cardero, M.E., Barron, A. and Gomez, L. 2000. NAFTA's impact on the female work force in Mexico. Mexico City, UNIFEM.

Carr, M. and Chen, M.A. 2002. Globalization and the informal economy and how trade and investment impact on the working poor. Working Paper on the Informal Economy No.1. Geneva, ILO.

Carr, M. 2002. "Challenging globalization: The response of women workers and entrepreneurs to trade and investment policies", in Newell, P., Rai, S. and Scott, A. (eds.), Development and the challenge of globalization. London: ITDG Publishing.

---- 1998. Gender implications of globalization (with specific reference to the Asian financial crisis). Paper presented at the "Roundtable on the Specific Implications of the Effects of the Asian Financial Crisis on Women in Asia." Women in Development and Gender Equity Division, Policy Branch, Canadian International Development Agency, Ottawa. March.

Chatterjee, M., Chen, M.A. and Unni, J. (forthcoming) "Autonomy, security and voice: Informal women workers in Ahmedabad City, India", in Chen, M.A., Jhabvala, R. and Standing, G. (eds.), Reconceptualizing work. Geneva, ILO. 
Chen, M.A., Jhabvala, R. and Lund, F. 2002. Supporting workers in the informal economy: A policy framework. Working Paper on the Informal Economy No. 2. Geneva, ILO.

Chen, M.A. and Snodgrass, D. 2001. Managing resources, activities, and risk in urban India: The impact of SEWA Bank. Washington, DC, USAID AIMS Paper.

Commonwealth Secretariat. 2002. Commonwealth businesswomen: Trade matters, best practices and success stories. London.

Dolan, C., Harris-Pascal, C. and Humphrey, J. 1999. Horticulture commodity chains: The impact of the UK market on the African fresh vegetable industry. Working Paper No. 96. Sussex, Institute of Development Studies.

Dolan, C. and Tewari, M. 2001. "From what we wear to what we eat: Upgrading in global value chains", in The value of value chains: Spreading the gains from globalisation. IDS Bulletin, 32(3), July.

Fisher, T. and Mahajan, V. 1997. The forgotten sector: Non-farm employment and enterprise in rural India. London, IT Publications.

Fontana, M., Joekes, S. and Masika, R. 1998. Global trade expansion and liberalization: Gender issues and impacts. BRIDGE Report No. 42. Sussex, Institute for Development Studies.

Forstater, M., MacDonald, J. and Raynard, P. 2002. Business and poverty: Bridging the gap. London, Resource Centre for the Social Dimensions of Business Practice.

Ge, W. 1999. The dynamics of export-processing zones. UNCTAD Discussion Paper No. 144

Gereffi, G., Humphrey, J. and Sturgeon, T. (forthcoming). "The governance of global value chains: An analytic framework", in Review of International Political Economy.

Gereffi, G. et al. 2001. "Introduction: Globalization, value chains and development", in The value of value chains: Spreading the gains from globalisation. IDS Bulletin, 32(3), July.

Gereffi, G. 1999. "International trade and industrial upgrading in the apparel commodity chain", in Journal of International Economics. 48(1): 37-70.

Ghiara, R. 1999. "Impact of trade liberalisation on female wages in Mexico: An econometric analysis", in Development Policy Review. 17(2): 171-190.

Ghosh, J. 1999. "An Asian view of globalization, employment, environment and development", in Trade. sustainable development and gender. New York and Geneva, UNCTAD.

----. 1995. Trends in female employment in developing countries: Emerging issues. Background Paper for the Human Development Report 1995. New York, UNDP.

Gibbon, P. 2001. "Agro-commodity chains: An introduction", in The value of value chains: Spreading the gains from globalisation. IDS Bulletin, 32(3), July.

Gore, C. and Figueiredo, J. (eds.). 1999. Social exclusion and anti-poverty policy: A debate. Geneva, IILS/UNDP.

Hart, G. 2002. Reworking Apartheid legacies: Global competition, gender and social wages in South Africa. 1980-2000. Social Policy and Development Paper No. 13.

International Institute for Environment and Development. 1997. Changing consumption and production patterns: Unlocking trade opportunities. Department of Policy Coordination and Sustainable Development. New York, United Nations.

IILS. 1998. Global production and local jobs: New perspectives on enterprise networks, employment and local development policy. Report presented at IILS International Workshop, 9-10 March. International Institute for Labour Studies. Geneva, ILO.

ILO. 1998. Labour and social issues relating to export processing zones. Labour Law and Labour Relations Branch. Geneva. 
---. 2002a. Decent work and the informal economy. Report IV, International Labour Conference, 90th Session. Geneva.

----. 2002b. Women and men in the informal economy: A statistical picture. Geneva.

ITDG. 2001. Impact of globalization on women homebased workers and producers in the food processing sub-sector in South Asia. Paper prepared for WIEGO/IDRC. Intermediate Technology Development Group South Asia.

IUCN. 1997. Big fish, small fry (pamphlet of the video). Gland, Switzerland, The World Conservation Union.

Jenkins, R., Pearson, R. and Seyfang, G. 2002. "Introduction", in Seyfang, G. Jenkins, R. and Pearson, $\mathrm{R}$ (eds.), Corporate responsibility and labour rights: Codes of conduct in the global economy. London and Sterling, Earthscan.

Jhabvala, R. and Kanbur, R. 2002. Globalization and economic reform as seen from the ground: SEWA's experience in India. Cambridge, MIT.

Joekes, S. 1995. Trade related employment for women in industry and services. Occasional Paper No. 5. Geneva, UNRISD.

---. 1999. "A gender-analytical perspective on trade and sustainable development", in Trade. sustainable development and gender. New York and Geneva, UNCTAD.

Johansson, H. and Nilsson, L. 1997. "Export processing zones as catalysts", in World Development. 25(12): $2115-28$.

Jureidini, R. 2002. "Temporary contract labour and xenophobic practices in the Middle East", in UNRISD News. No. 25, Autumn/Winter.

Kabeer, N. 2000. The power to choose: Bangladeshi women and labour market decisions in London and Dhaka. London, Verso.

---. 2000. "Social exclusion, poverty and discrimination: Towards an analytical framework", in IDS Bulletin. 31(4)

Litchfield, J. and McCulloch, N. 2003. Poverty in Zambia: Assessing the impacts of trade liberalisation in the 1990s. Poverty Research Unit Working Paper No. 16. University of Sussex.

Lovering, J. 1998. "Globalization, unemployment and 'social exclusion' in Europe: Three perspectives on the current policy debate", in International Planning Studies. 3(1): 35-56.

Lund, F. and Nicholson, J. (eds.). 2004. Chains of production, ladders of protection: Social protection for workers in the informal economy. Washington DC, World Bank.

Madeley, J. 2000. Trade and hunger: An overview of case studies on the impact of trade liberalization on food security. Stockholm, Forum Syd.

Mitter, S. 2003. Globalization and ICT: Employment opportunities for women. Paper prepared for the Gender Advisory Board. United Nations Commission on Science and Technology for Development.

National Commission on Labour. 2001. Report of the Group on Women and Child Labour. Government of India.

Nayak, P. 1995. "Economic development and social exclusion in India", in Social exclusion and South Asia. Geneva, ILO. 
Prieto, M., Hadjipateras, A. and Turner, J. 2002. "The potential for codes as part of women's organizations' strategies for promoting the rights of women workers: A Central America Perspective", in Seyfang, G. Jenkins, R. and Pearson, R.(eds.), Corporate responsibility and labour rights: Codes of conduct in the global economy. London and Sterling, Earthscan.

Qureshy, L.F. and Velia, M. 2002. The EU clothing sector: Trade policy and value chain restructuring. Poverty Research Unit Notes No. 7. Sussex.

Rodgers, G., Gore, C. and Figueriedo, J. (eds.). 1995. Social exchision: Rhetoric, reality responses Geneva: IILS/UNDP.

Shiva, V. 2000. Stolen harvest: The hijacking of the global food supply. London, South End Press.

Singh, N. 2001. Gendered labour market and trade in South Asia: An issues paper. Ottawa, IDRC

Skinner, C. and Valodia, I. (undated). Labour market policy, flexibility, and the future of labour relations: The case of KwaZulu-Natal clothing industry. (mimeo) Durban, University of Natal.

Stein, N. 2003. "Labor trade: No way out", in Fortune. 147(1), 20 January: 102.

UNCTAD. 2002. "Gender, e-commerce and development", in E-commerce and development report 2002 .

United Nations. 1999. 1999 World survey on the role of women in development: Globalization. gender and work. New York.

Unni, J. 2002. Globalization and securing worker rights for women in developing countries. Gujurat Institute for Development Research, Working Paper No. 132.

Vasudeva, P. and Justino, P. 2001. Trade and poverty. Poverty Research Unit Notes No. 5. Sussex.

Weatherspoon, D. and Reardon, T. 2003. "The rise of supermarkets in Africa: Implications for agrifood systems and the rural poor", in Development Policy Review. 21(3), May: 333-355..

Wee, V. (ed.). 1998. Trade liberalization: Challenges and opportunities for women in Southeast Asia. Bangkok: UNIFEM/ENGENDER.

Wilshaw, R. 2002. "Code monitoring in the informal fair trade sector: The experience of Oxfam GB", in Seyfang, G. Jenkins, R. and Pearson, R.(eds.), Corporate responsibility and labour rights: Codes of conduct in the global economy. London and Sterling, Earthscan.

Winters, L.A. 2000. Trade liberalisation and poverty. Poverty Research Unit Working Paper No. 7. Sussex 


\section{Policy Integration Department Working Papers prepared for the World Commission on the Social Dimension of Globalization}

No. 16 International finance: Meeting the needs of people in developing countries, José Guilherme Almeida dos Reis

No. 17 The gender dimensions of the globalization of production, Stephanie Barrientos, Naila Kabeer and Naomi Hossain

No. 18 Social exclusion in the context of globalization, Jan Breman

No. 19 Gender and globalization: A macroeconomic perspective, Çağatay Nilüfer and Ertiik Korkurt

No. 20 Globalization, social exclusion, and work: with special reference to informal employment and gender, Marilyn Carr and Martha Chen

No. 21 Resources for social development, Anthony Clunies Ross

No. 22 Does the new international trade regime leave room for industrialization policies in the middle-income countries?, Alisa DiCaprio and Alice Amsden

No. 23 Social dimension of globalization in Latin America: Lessons from Bolivia and Chile, Alvaro Garcia Hurtado

No. 24 Globalization: Social impact and policy actions: A partly annotated bibliography, Bernhard Gunter and Rolph van der Hoeven

No. 25 The social dimension of global production systems, Susan Hayter

No. 26 Reforming global economic and social governance: a critical review of recent programmatic thinking, Jeremy Heimans

No. 27 Corporate social responsibility: An issues paper, Michael Hopkins

No. 28 Upgrading in global value chains, John Humphrey

No. 29 Implications of globalization and economic restructuring for skills development in Sub-Sahara Africa, Richard K. Johanson

No. 30 The outcome and impact of the main international commissions on development issues, Frédéric Lapeyre

No. 31 Globalization and structural adjustment as a development tool, Frédéric Lapeyre

No. 32 Globalization and perceptions of social inequality, Malte Luebker

No. 33 The changing structure of trade linked to global production systems: What are the policy implications?, William Milberg

No. 34 Corporate social responsibility: An overview of principles and practice, Jill Murray

No. 35 Inclusive development strategy in an era of globalization, Ignacy Sachs

No. 36 Social consequences of the globalization of the media and communications sector: Some strategic considerations, Seán ó. Siochrú

No. 37 Globalization, history and international migration - A view from Latin America, Andrés Solimano

No. 38 Towards a different kind of globalization, or how the anti-globalizers view the world, Gijsbert van Liemt 